\title{
Melintasi Batas Negara-Bangsa: Formasi Gerakan Perlindungan Hak Buruh Migran Domestik di Malaysia
}

\section{Irza Khurun'in}

Program Pascasarjana Hubungan Internasional, Universitas Gadjah Mada Bulaksumur, Yogyakarta 55281, Indonesia

khurunin.irza@gmail.com

Diserahkan: 09 November 2016, diterima: 09 Januari 2017

\begin{abstract}
The aim of this research is to understand the formation in the issues of migrant domestic workers' right protection in Malaysia by analyzing the transnational activism in four civil organizations, namely WAO (Women's Aid Organization), Tenaganita, NSI (North South Initiatives), and AOHD (Archdiocesan Office of Human Development). This research is qualitative research which use deep interview, obervation, and documentation in collecting the data. The formation and networking pattern are ranging from human rights claim, labour rights claim, claim of gender equlity at work, and humanitarian claim. There are fragmented collective identity, those are cosmopolitan identity, humanitarian activist, and part of each organization. Therefore, this research shows that citizenship is not barrier in doing humanitarian activities.

Keywords: Migrant Domestic Workers, Transnational Activism, Human Rights, Collective Identity, Rooted Cosmopolitan
\end{abstract}

\begin{abstract}
Abstrak
Penelitian ini bertujuan untuk melihat formasi gerakan di seputar isu perlindungan hak buruh migran sektor domestik di Malaysia dengan melihat aktivisme transnasional dari empat organisasi masyarakat sipil, yakni WAO (Women's Aid Organization), Tenaganita, NSI (North South Initiatives), dan AOHD (Archdiocesan Office of Human Development). Penelitian ini merupakan penelitian kualitatif dengan teknik pengumpulan data wawancara, observasi, dan dokumentasi. Formasi serta pola jejaring lintas batas gerakan tersebut berkisar antara klaim hak asasi manusia, hak-hak buruh, kesetaraan gender di tempat kerja, dan nilai kemanusiaan. Identitas kolektif gerakan terfragmentasi menjadi tiga, yakni identitas kosmopolitan, aktivis kemanusiaan, dan anggota organisasinya. Maka, penelitian ini menunjukkan bahwa kewarganegaraan bukan lagi pembatas dalam melakukan aksi kemanusiaan. Kata Kunci: Buruh Migran Domestik, Aktivisme Transnasional, Hak Asasi Manusia, Identitas Kolektif, Akar Kosmopolitan
\end{abstract}

\section{PENDAHULUAN}

Tulisan ini berusaha untuk mendeskripsikan formasi gerakan perlindungan hak asasi manusia terkait dengan isu buruh migran sektor domestik yang dilakukan oleh masyarakat sipil Malaysia. Relasi antara buruh migran dan masyarakat sipil menarik dibahas karena ada hubungan antara citizens dan non-citizens. Tulisan ini menunjukkan bahwa citizenship bukan sebagai penghalang dalam melakukan aksi kemanusiaan. Ada konstruksi identitas kolektif dibawah semangat universalisme sebagai warga dunia yang menjunjung nilai-nilai hak asasi manusia. Penelitian ini juga menjelaskan mengenai proses transnasionalisasi gerakan melalui pembingkaian aksi kolektif.

Malaysia memiliki tingkat dependensi yang tinggi terhadap ketersediaan buruh migran sektor domestik, sayangnya hal itu tidak diimbangi dengan perlindungan yang mengikat secara hukum. Pemerintah Malaysia belum mengatur secara khusus terhadap pekerja asing terutama yang bekerja di sektor domestik. Semua pekerja di Malaysia, baik pekerja dalam negeri maupun asing hanya diatur melalui kontrak kerja yang sah antara employer dengan employee (Pahroji \& Singadimedja, 2012). Buruh migran 
domestik di Malaysia terikat pada ketentuan aturan keimigrasian Malaysia sebagai warga negara asing yang berada di Malaysia untuk batas waktu tertentu (Pahroji \& Singadimedja, 2012).

Peran negara dalam memberikan perlindungan terhadap buruh migran masih minim. Minimnya peran negara dalam melindungi hak-hak buruh migran domestik memberikan ruang bagi aktor non negara untuk mengambil bagian dalam interaksi lintas batas ini. Maka muncul berbagai aktivisme yang dilakukan oleh masyarakat sipil seperti yang ada di Malaysia. Penulis mengambil fokus pada gerakan transnasional yang dilakukan oleh Civil Society Organisations (CSOs) di Malaysia, yakni Women's Aid Organizations (WAO), Tenaganita, North South Initiatives (NSI), dan Archdiocesan Office for Human Development (AOHD). Empat organisasi tersebut dipilih sebagai sampel untuk melihat formasi gerakan perlindungan buruh migran di Malaysia. Penulis memilih empat organisasi tersebut karena keempatnya aktif berkecimpung dalam advokasi perlindungan hak buruh migran domestik. Selain itu, keempatnya mewakili kelompok suku bangsa yang ada di Malaysia, yakni India, Melayu, dan China. Pengelompokan ini menunjukkan bahwa di Malaysia sangat erat identitas kebangsaannya yang kemudian dihadapkan dengan fenomena migrasi internasional yang memaksa mereka untuk melebur dengan masyarakat transnasional dari berbagai negara bangsa.

\section{KERANGKA PEMIKIRAN}

Konsep pertama yang digunakan adalah konsep aktivisme transnasional untuk menjelaskan mekanisme dan proses perluasan gerakan ke level internasional. Dalam aktivisme transnasional ada upaya untuk membangun identitas kolektif. Maka, di konsep kedua, penulis menggunakan konsep identitas kolektif dari pemikiran Alberto Melucci untuk menjelaskan tentang konstruksi identitas dalam aksi kolektif. Selanjutnya, untuk menjelaskan strategi yang digunakan oleh gerakan sosial tersebut, penulis menggunakan konsep framing collective action oleh Benford dan Snow dan transnational advocay network oleh Keck dan Sikkink.

\section{AKTIVISME TRANSNASIONAL}

Konsep aktivisme transnasional menjadi backbone dalam tulisan ini. Dalam bukunya The New Transnational Activism, Sidney Tarrow menjelaskan proses transformasi posisi dalam ide dan gerakan lintas batas dan berakar pada lokalitas. Sebagai agenda transformatif, Tarrow menekankan bahwa aktivisme transnasional dapat mengubah aktor dalam protes domestik menjadi pelaku gerakan transnasional dengan tetap mengakar pada konteks sejarah dan kultur gerakan lintas batas. Transformasi tersebut bisa menjadi jembatan dalam gerakan sosial dari level lokal menuju global melalui 3 sets of processes (Tarrow, 2005, hal. 2). Pertama, level domestic ground yang terdiri dari global framing dan internalization di ranah domestik dengan isu dalam negeri menjadi fokusnya. Level yang kedua adalah 'proses transisi', dimana ada dua aktivitas yakni diffusion dan scale shift. Dalam proses transisi ini bisa terjadi di ranah lokal maupun internasional dengan isu yang lebih variatif dari berbagai level. Yang terakhir adalah level internasional, yakni terdapat proses eksternalisasi dan koalisi transnasional (Tarrow, 2005, hal. 32). Keenam rangkaian tersebut dapat berjalan secara terpisah maupun berkombinasi. Konsep tersebut membantu penulis untuk mengilustrasikan aktivisme transnasional yang dilakukan oleh empat CSO di Malaysia baik secara sendiri-sendiri maupun kolektif dalam memperjuangkan hak-hak buruh migran domestik.

Tiga premis yang ditekankan Tarrow tentang aktivisme transnasional adalah aktivisme transnasional memiliki proses sejarah; merupakan refleksi dari globalisasi; serta dibentuk oleh perubahan kesempatan struktur dalam politik internasional. Selaras dengan premis Tarrow, Ilcan dan Lacey (2013) juga mengatakan bahwa aspek historis, sosial, dan kondisi politik menjadi pertimbangan yang penting untuk mempengaruhi bentuk aktivisme transnasional. Aktivisme transnasional berakar pada lokalitas dan jatuh pada kondisi dunia yang kosmopolitan. Sementara globalisasi dalam aktivisme transnasional 
memberikan insentif berupa proses internasionalisasi yang menawarkan karangka serta kumpulan poin-titik fokus serta struktur bagi aktivis internasional (Tarrow, 2005, hal. 3). Terakhir, perubahan struktur dalam politik internasional menyumbang dua mekanisme kemunculan aktivisme transnasional yakni melalui dua mekanisme, difusi dan mobilisasi.

Sidney Tarrow (2005) melihat dasar kemunculan aliansi kampanye transnasional ini sebagian besar berakar kosmopolitan (rooted cosmopolitan).

Kosmopolitan merujuk pada perasaan menjadi bagian dari dunia secara keseluruhan, tidak dibatasi pada salah satu kelompok atau bagian (Tarrow, 2005, hal. 40). Kampanye global tentang perlindungan hak buruh migran tidak lepas dari akar kemanusiaan yang bersifat universal. Ada transisi dari tatanan negarabangsa menuju pada tatanan kosmopolitan yang secara signifikan menggeser hukum internasional pada hak asasi manusia. Ulrich Beck meletakkannya pada dua kondisi, fist age modernity dan second age modernity. Pada modernitas pertama, hukum internasional mendahului hak asasi manusia (Beck, 2000, hal. 83). Namun pada modernitas kedua, hak asasi manusia mendahului hukum internasional.

\section{IDENTITAS KOLEKTIF}

Di bagian sebelumya telah dijelaskan mengenai munculnya aktivisme transnasional yang tidak terlepas dari identitas kolektif yang mencoba dibentuk. 'Selfdefined' atau pendefinisian diri berkaitan dengan konstruksi identitas atas respon terhadap event internasional sehingga memunculkan sebuah 'sense of collective identity' diantara kelompok negara. (Tarrow, 2005, hal. 22) Artinya, kelompok negara dalam konteks ini adalah kampanye kolektif dari NGOs di Malaysia untuk menyuarakan advokasi perlindungan terhadap hak-hak buruh migran domestik.

Menyatukan beragam individu dan kelompok ke dalam sebuah gerakan atau kampanye, maka perlu mengidentifikasi identitas kolektif yang dibentuk.

Identitas kolektif adalah sebuah pemahaman akan diri yang terkonstruksi oleh 'interactive' dan 'shared'. Pada analisis gerakan sosial, identifikasi identitas kolektif adalah penting untuk melihat peleburan aktor gerakan dalam sebuah perjuangan untuk melawan musuh bersama. Untuk mengidentifikasi musuh bersama, subjek berusaha menggemakan ide-ide mereka pada level kolektif di mana akhirnya mereka bisa bersatu, baik karena adanya persamaan maupun perbedaan (C.R.S. Milani, 2007, hal. 18). Secara definitif, Melucci (1996:70) menyatakan bahwa identitas kolektif adalah sebuah interaksi dan shared definition yang dihasilkan oleh sekelompok individu atau kelompok dengan tujuan tertentu (Melucci, 1996, hal. 70). Aksi kolektif diartikan sebagai produk negosiasi tujuan di mana sejumlah perspektif, makna, dan hubungan mengkristal menjadi pola tindakan dalam "sistem tindakan multipolar" (Melucci, 1989, hal. 332).

\section{PEMBINGKAIAN AKSI KOLEKTIF}

Dalam penjelasan sebelumnya telah dijelaskan bahwa salah satu strategi dalam aktivisme transnasional adalah framing collective action. Tarrow dalam bukunya The New Transnational Activism menjelaskan mengenai global framing yang mana ia mendefinisikannya sebagai penggunaan simbol eksternal untuk orientasi lokal atau klaim nasional (Tarrow, 2005, hal. 60). Pada akhirnya, akar kosmopolitan-lah yang dianggap sebagai langkah dalam pembentukan sebuah pembingkaian serta pemunculan identitas kolektif. Namun, sebelumnya penting untuk melihat apa itu framing.

Konsep 'framing' digunakan untuk menjelaskan bagaimana sebuah gerakan mendefinisikan sebuah masalah (diagnostic framing), merancang solusi untuk menyelesaikan masalah tersebut (prognostic framing), dan memobilisasi pengikut baru untuk penyebab masalah tersebut (motivational framing) (Benford \& Snow, 2000, hal. 615). Dalam konteks ini, gerakan sosial tidak hanya dipahami sebagai pembawa ide yang telah ada, tidak pula dipahami sebatas pergerakan otomatis akibat dari susunan struktural, kondisi yang ada, maupun ideologi yang telah berkembang (Benford \& Snow, 2000, hal. 613). Terlebih, aktor gerakan dilihat sebagai agen 'penanda' yang secara aktif terlibat dalam produksi dan pemeliharaan makna bagi konsituen, 
antagonis, dan para pengamat (Benford \& Snow, 2000, hal. 613). Aktor-aktor tersebut terlibat aktif bersama dengan aktor state seperti negara maupun pemerintah daerah serta media dalam melakukan 'politik pemaknaan' (Benford \& Snow, 2000, hal. 613). Di dalam 'politik pemaknaan', terdapat istilah 'Framing as Meaning Construction'. Maksudnya adalah di dalam 'framing' terdapat signifying work atau aktor yang bergerak sebagai penanda untuk melakukan konstruksi pemaknaan. Benford dan Snow menjelaskan 'framing' sebagai sebuah fenomena prosesual. Disebut prosesual karena dalam realitanya terdapat proses dan dinamika dalam melakukan pembingkaian atau framing itu sendiri. Maka, hasil dari produk tersebut disebut sebagai 'collective action frame' (Benford \& Snow, 2000, hal. 613).

\section{JARINGAN ADVOKASI TRANSNASIONAL}

Jaringan advokasi transnasional bukan hal baru dalam studi gerakan sosial. Keck dan Sikkink tidak terlalu memperhatikan fenoma globalisasi sebagai faktor kemunculan jaringan transnasional, namun lebih pada shared value, common discourse, dan shared idea. Meskipun, dalam sebuah jaringan aktivisme transnasional tidak mengesampingkan adanya pertimbangan terkait insentif, hambatan, strategi, institusi, dan aturan-aturan tertentu. Konsep transnational network atau jaringan transnasional ala Keck dan Sikkink ini merupakan perkawinan dua tradisi, yakni tradisi sosiologi dan politik internasional. Artinya, konsep networking yang dibangun melalui gagasan aktivisme atau gerakan diaplikasikan secara lintas bangsa, yang kemudian menjembatani antara keilmuan Hubungan Internasional dan studi Perbandingan Politik (Keck \& Sikkink, 1999, hal. 90).

Konsep jaringan advokasi transnasional yang diusung oleh Keck dan Sikkink dengan menteorisasikan hubungan jaringan lintas batas dengan apa yang disebut dengan "Boomerang Effect" di mana aktor non-state menghadapi represi dan blokade di level domestik. Tarrow menjelaskan bahwasanya boomerang effect tersebut merupakan proses eksternalisasi yang bekerja melalui urutan tahapan yang berbeda. Pertama, hubungannya dalam konteks dalam negeri; kedua adalah pembingkaian pertentangan; dan yang ketiga adalah bentuk dari aksi kolektif (Tarrow, 2005, hal. 147). Sebuah jaringan internasional terus berproliferasi dan bertujuan untuk mengubah perilaku sebuah negara dan organisasi internasional (Keck \& Sikkink, 1998, hal. 2). 'Pembingkaian' menjadi bagian penting dalam jaringan advokasi internasional. Aktor-aktor yang terlibat secara simultan melakukan pembingkaian isu supaya mudah dipahami oleh target audiences, untuk menarik perhatian dan untuk mendorong aksi (Keck \& Sikkink, 1998, hal. 2). Selain itu juga bertujuan untuk mencocokkan dengan venue institusional.

Jaringan advokasi transnasional muncul dengan adanya kondisi dimana terdapat boomerang pattern, political entrepreneurs, dan pertumbuhan konferensi internasional. Boomerang pattern disini maksudnya adalah kondisi dimana adanya hambatan di dalam struktur penghubung antara kelompok lokal dan pemerintah (Keck \& Sikkink, 1998, hal. 12). Selain itu, para aktivis mengangap bahwasanya 'jaringan' tersebut dapat memajukan misi-misi kampanye serta secara aktif mempromosikan ide-ide yang mereka perjuangkan (Keck \& Sikkink, 1998, hal. 12). Banyak diantara jaringan advokasi yang ada mengangkat isu 'hak' di dalam kampanye mereka. Hal tersebut muncul karena mereka meyakini bahwa pemerintah, selain sebagai 'penjamin hak' juga sebagai 'pelanggar hak' sehingga memunculkan political entrepreneurs. Kondisi terakhir yang memungkinkan sebuah jaringan advokasi transnasional terbentuk adalah karena adanya konferensi internasional sebagai wadah interaksi untuk membentuk dan menguatkan jaringan.

\section{HASIL DAN PEMBAHASAN}

Pada bagian pembahasan, penulis membagi menjadi tiga bagian. Yang pertama menjelaskan tentang sejarah kemunculan gerakan perlindungan hak buruh migran domestik di Malaysia, fragmentasi identitas kolektif, serta proses transnasionalisasi di level domestik yakni melalui pembingkaian global dan internalisasi. Pada 
bagian ini penulis menjelaskan bahwa formasi gerakan perlindungan hak buruh migran berkisar antara klaim kemanusiaan, hak asasi manusia, gender equality at work, dan hak-hak buruh. Kedua, merupakan uraian mengenai proses transnasionalisasi gerakan di level transisi dan internasional. Peluang transnasionalisasi gerakan tidak lepas dari perubahan lingkungan politik internasional dan nasional serta akar kosmopolitan yang berpengaruh pada pembentukan identitas kolektif. Dan yang terakhir menguraikan tentang strategi mobilisasi politik yang terbagi dalam tiga level, yakni level grassroot, level nasional, dan level internasional.

\section{MENJADI WARGA DUNIA? SEBUAH FRAGMENTASI IDENTITAS KOLEKTIF}

Ide tentang transnasionalisme ini berangkat dari penolakan masyarakat sipil terhadap opresi negara. Ide tentang nilai 'hak asasi' yang universal tidak selaras dengan adanya tekanan yang diberikan oleh negara terhadap rakyatnya. Transnasionalisme dan kosmopolitanisme adalah dua konsep yang popular dalam diskursus para akademisi maupun jurnalis. Keduanya belum memiliki definisi universal yang disepakati dalam literatur. Transnasionalisme secara original terhubungan dengan aktifitas imigran, meskipun konsep tersebut telah meluas ke kelompok yang lain seperti halnya serangkaian aktivitas lintas batas (Roudometof, 2005, hal. 113).

Kosmopolitanisme telah digunakan sebagai sudut pandang moral baru dan etnis yang baru yang sesuai dengan abad 21, namun seringkali dikritik karena dianggap sebagai sebuah manifestasi dari mentalitas kelas menengah keatas (Roudometof, 2005, hal. 113). Transnasionalisme lebih sering diafiliasikan pada kegiatan migrasi yang terjadi secara besar-besaran di tahun 1990-an. Selama satu dekade terakhir ini, label telah lebih meluas pada kelas kapital, juga terhadap aktivis lintas batas, komunitas agama dan gerakan sosial (Roudometof, 2005, hal. 115).

Fragmentasi identitas terbagi menjadi tiga kategori, yang pertama identitas kosmopolitan sebagai citizens of the world. Yang kedua adalah identitas sebagai aktivis kemanusiaan dan yang ketiga adalah identitas sebagai anggota di masing-masing organisasi. Pertama, pembentukan identitas kosmopolitan diawali dengan identifikasi diri sebagai konsituen (protagonist identity) yaitu sebagai bagian dari warga dunia. Identifikasi diri sebagai upaya bagi aktor gerakan melebur di dalam sebuah perjuangan yang lebih besar untuk melawan aktor lain yang dianggap sebagai 'musuh bersama'. Aktor gerakan mendefinisikan diri sebagai bagian dari warga dunia yang meyakini kebenaran moral dan etika universal yakni nilai-nilai kemanusiaan. Bahwasanya semua manusia memiliki derajat yang sama dan berhak memperoleh hak-hak asasi manusia serta dijunjung harkat dan martabatnya. Dengan menjadi bagian dari warga dunia, aktor gerakan berusaha untuk menghilangkan batasan antara pelaku gerakan perlindungan buruh migran di Malaysia dengan buruh migran itu sendiri. Selain itu, aktor gerakan mendefinisikan diri mereka sebagai bagian dari warga dunia, sama halnya dengan buruh migran. Aktor gerakan menempatkan buruh migran sebagai subjek dalam aktivitasnya.

Dimensi kosmopolitanisme tercermin dalam landasan gerakan organisasi-organsiasi. Misalnya WAO dengan misinya untuk mempromosikan penghormatan, perlindungan dan pemenuhan kesetaraan hak bagi perempuan. Atau Tenganita yang memiliki misi untuk mempromosikan dan melindungi hak-hak dan martabat semua wanita, migran, pengungsi. Senada dengan dua organisasi sebelumnya, NSI juga memiliki misi yakni "justice and dignity for all". Visi AOHD adalah 'Bersatu dengan Tuhan, dalam solidaritas dengan seluruh umat manusia". Lebih lanjut lagi, prinsip tentang kesetaraan dan martabat untuk semua manusia terlihat dalam pendapat pihakpihak yang diwawancarai. Natasha megatakan bahwa, "And for everything we do, is to promote basic human right and gender equality for all people" (Wawancara dengan Natasha, WAO, pada 17 Juni 2016). Adrian, direktur NSI dengan tegas menjelaskan bahwa apa yang mereka lakukan adalah untuk "Serve the people". Senada dengan dua aktivis di atas, konsep dignity adalah moral universal yang berpengaruh pada aktivitas AOHD. Josephine 
mengatakan "Dignity is for all people.... But I think even the begar also has dignity. Or thief also has dignity" (Wawancara dengan Josephine, The Migrant and Refugees Desk AOHD tanggal 20 Juni 2016).

Kedua, pembentukan identitas sebagai aktivis kemanusiaan. Aktor gerakan mengklaim diri mereka sebagai human rights defender serta berupaya untuk memberikan jarak dengan objek gerakan yakni buruh migran sektor domestik. Posisi mereka sebagai aktivis kemanusiaan sangat kental terlihat ketika melakukan advokasi perlindungan hak buruh migran baik di level akar rumput, nasional, maupun internasional. Aktor gerakan memposisikan buruh migran sebagai kelompok yang rentan, hal tersebut penanda bahwa 'kita' (us) adalah aktivis, sedangkan 'mereka' (other) terdiri dari objek sasaran dan 'musuh bersama'.

Beberapa kegiatan yang dilakukan untuk menunjukkan diri mereka sebagai humanitarian activist. Women's Aid Organization misalnya, yang cenderung meletakkan klaim mereka pada anti diskriminasi terhadap perempuan. Artinya, WAO memperjuangkan adanya gender equality at work. Dalam aksi-aksi yang dilakukannya, WAO juga banyak menggunakan argumentasi CEDAW sebagai landasan internasional aktivismenya. Sementara Tenaganita meletakkan klaim hak buruh migran serta anti diskriminasi terhadap perempuan sebagai klaim utamanya. Tenaganita banyak mengadopsi konvensi ILO dan CEDAW sebagai argumentasi aktivismenya.

Fragmentasi identitas kolektif yang ketiga adalah identitas sebagai anggota organisasi. Identitas sebagai anggota organisasi ini sebagai pembeda antar aktivis di organisasi yang satu dengan yang lain. Masing-masing organisasi berusaha untuk membedakan diri dengan organisasi lain sebagai bentuk pendefinisian diri sebagai anggota organisasi tersebut. Konsep 'ke-kita-an' dibangun untuk membentuk solidaritas dalam satu organisasi secara internal. Anggota dari WAO, di beberapa dimensi menyebut diri mereka 'WAO'. Begitu pula dengan anggota dari Tenaganita, NSI, maupun AOHD. AOHD, dalam dimensi ke dalam organisasi, mereka cenderung mendefinisikan diri sebagai 'Kelompok Gereja' yang mengambil ranah kerjasama antar gereja dalam menyelesaikan beberapa problem terkait dengan advokasi buruh migran.

Pendefinisian diri terlihat ketika mereka tergabung dalam aliansi NGO yang memberikan perhatian terhadap kasus migrasi internasional, yakni Migration Working Group (MWG). Masing-masing organisasi memiliki ranahnya sendiri dalam menjalankan advokasi hak-hak buruh migran. Organisasi yang memiliki shelter seperti WAO dan Tenaganita sering melaksanakan advokasi secara langsung pada buruh migran yang bermasalah. Berbeda dengan NSI dan AOHD yang tidak memiliki shelter, mereka berjuang di lini yang lain. Josephine menjelaskan:

"Kalau organisasi ini boleh tolong shelter, dia boleh kasih perlindungan. satu bikin konseling. Bagi-bagi tugas supaya lebih fokus untuk hantar sesiapa. Satu orang tak boleh lakukan semua."(Wawancara dengan Josephine, The Migrant and Refugees Desk AOHD tanggal 20 Juni 2016).

Artinya, ada limited cosmopolitanism dalam pendefinisian diri yang dilakukan oleh aktor. Kosmopolitan menjadi pintu masuk bagi aktivis gerakan untuk melegitimasi posisi dengan semangat kemanusiaan yang universal. Namun kondisi tersebut dibatasi oleh kepentingan di masing-masing organisasi. Kembali pada preposisi Melucci bahwa identitas kolektif adalah semu, maka terlihat dari kolektifitas yang ada dalam gerakan kolektif tersebut.

\section{RESISTENSI MASYARAKAT SIPIL DAN \\ TRANSNASIONALISASI GERAKAN}

Pentingnya pengkajian terkait buruh migran sektor domestik didasari oleh tiga faktor, pertama yakni tingginya ketergantungan Malaysia terhadap ketersediaan buruh migran sektor domestik. Namun buruh migran domestik ditempatkan sebagai 'secondclass humans' diantara masyarakat Malaysia dan sekaligus memegang peranan penting dalam sektor pemenuhan angkatan kerja sektor informal. Melihat kenyataannya, jika tidak ada arus migrasi di sektor pekerja rumah tangga ke Malaysia, keluarga di Malaysia akan kekurangan tenaga kerja sektor tersebut. Kedua, 
relasi buruh migran domestik dengan struktur sosial di Malaysia. Persepsi gender yang mendarah daging di dalam masyarakat Malaysia bahwasanya pekerja rumah tangga adalah anggota rumah tangga yang tidak memerlukan perlindungan hukum formal. Hal itu yang turut berkontribusi pada kemunculan konflik laten antara kelompok buruh migran dengan masyarakat dan pemerintahan Malaysia. Ketiga adalah terkait dengan kondisi politik Malaysia itu sendiri yang tidak memberikan ruang kebebasan bagi buruh migran, khususnya yang bekerja di sektor rumah tangga.

Hal senada diungkapkan oleh Juanita Elias. Stigma negatif terhadap buruh migran domestik akibat dari ketakutan sosial terhadap hubungan intim antara pekerja domestik dan anggota keluarga (Elias, 2008, hal. 19). Hal tersebut bermain dalam diskursus kontrol sosial terhadap buruh migran. WAO, sebagai salah stau organsisasi yang bergerak di bidang perlindungan hak perempuan juga mengungkapkan hal yang sama. Problem yang muncul terkait dengan buruh migran domestik salah satunya karena stereotype negatif masyarakat di Malaysia terhadap kelompok tersebut bahwa pekerja domestik tidak bisa dipercaya, 'husband stealer', dan 'sexually promiscuous' (Elias, 2008 hal. 20).

Pemerintah tidak memberikan dukungan terhadap penelitian baik lokal maupun internasional, sementara NGOs sendiri memiliki sumber daya yang terbatas untuk melakukan analisis kritisnya (Weiss \& Hassan, 2002, hal. 17). Kendati demikian, gerakan perempuan maupun gerakan-gerakan lain yang berbasis masyarakat sipil mengalami hambatan dalam aktivitasnya. Faktor yang paling signifikan menghambat perkembangan advokasi berorientasi NGOs adalah peraturan pemerintah Malaysia (Weiss \& Hassan, 2002, hal. 30). Malaysia memiliki Internal Security Act yang digunakan untuk mendisiplinkan aksi dari kelompok-kelompok yang terlihat megancam stabilitas politik pemerintahan (Lyons, 2006, hal. 4). Aturan tersebut diperkenalkan pada masa penjajahan Britania dan digunakan untuk melawan serangan politik dari komunis. Dan saat ini, ISA tersebut digunakan untuk melawan ancaman yang kemungkinan dapat dianggap membahayakan keamanan nasional. Di Malaysia, Artikel 10 dari konstitusi Malaysia menjamin kebebasan berpendapat, berekspresi, berkumpul dan berserikat, namun semua terbatas sepanjang tidak mengganggu kepentingan pemerintah dalam menjaga stabilitas keamanan dan ketertiban umum.

Hukum lainnya yang juga memberikan batasan terhadap pergerakan NGOs maupun aktivis adalah Police Act 1967 (telah diamandemen pada 1988) yang melarang adanya protes secara spontan. Dalam aturan tersebut disebutkan bahwa diharuskan mendapat izin polisi empat belas hari sebelumnya untuk setiap pertemuan publik yang dihadiri lebih dari lima orang (Weiss \& Hassan, 2002, hal. 34). Dan yang lebih buruk lagi, seringkali polisi tidak mau memberikan surat izin tersebut. Alih-alih melakukan aksi massa untuk mendapatkan perhatian dari masyarakat maupun pemerintah, banyak NGOs yang mengambil jalan lain, misalnya dengan mengadakan seminar, simposium, dan publikasi dari hasil tulisan atau penelitian yang mereka lakukan. Hal itu sebagai respon mereka terhadap pembatasan yang cukup ketat.

Lebih jauh lagi, pembatasan yang dilakukan pemerintah untuk menekan aksi-aksi dari gerakan sosial adalah dengan adanya Printing Presses and Publication Act 1984 yang telah diamandemen pada tahun 1987. Dalam regulasi tersebut disebutkan bahwa untuk semua publikasi harus mendapatkan izin tahunan dari Ministy of Home Affairs begitu juga dengan undang-undang pencemaran nama baik, penghinaan terhadap pengadilan dan rahasia resmi menjadi aturan baku yang tidak bisa dilanggar. Ketika beberapa NGOs mengambil alternatif sebagai perusahan publishing, masih harus dihadapkan dengan aturan ketat terkait dengan semua publikasinya.

Selain melalui Internal Security Act, Artikel 10 Konstitusi Malaysia, Police Act 1967, Printing Presses and Publication Act 1984, dari segi pendidikan juga ada Universities and University Colleges Act 1971 atau UUCA yang telah diamandemen pada 1975 juga menjadi salah satu pembatas gerakan sosial yang bisa berasal dari gerakan mahasiswa. Pemerintah Malaysia melihat 
kampus sebagai agen penting untuk mobilisasi politik, oleh karenanya diberlakukannya UU tersebut guna melarang mahasiswa terlibat dalam kegiatan politik (Weiss \& Hassan, 2002, hal. 34).

Dalam level domestik terdapat agenda pembingkaian isu, baik itu secara diagnostic framing maupun prognostic framing. Diagnostic framing adalah pemaparan bentuk-bentuk ketidakadilan oleh aktor gerakan. Berdasar hasil wawancara langsung pada keempat organisasi gerakan tersebut, keempatnya berpendapat sama dalam memaparkan kondisi buruh migran domestik. Berbagai kondisi yang disebutkan diantaranya adalah tidak adanya perlindungan bagi buruh migran sektor domestik yang termaktub dalam employment act Malaysia; gaji yang tidak dibayar; majikan merampas paspor pekerja; banyak pekerja yang tidak mendapatkan day off; tidak dibolehkan bagi pekerja untuk membentuk serikat pekerja; adanya physical abuse; serta seringkali pekerja mendapatkan perlakuan kasar salah satunya dengan menyebut sebagai 'servant'. Lebih dari itu, pekerja tidak mendapatkan hak untuk maturnity life, tidak mendapatkan tempat tinggal yang layak, serta jam kerja yang tidak jelas.

Beragam pelanggaran HAM yang dialami oleh buruh migran diantaranya adalah tidak diberikan kebebasan untuk berasosiasi, dan banyak diantaranya tidak mendapatkan kontrak kerja yang jelas. Natasha juga menyebutkan bahwa hal yang paling penting adalah aspek bahasa. Bahasa menjadi salah satu barrier bagi tenaga kerja asing di Malaysia. Natasha, Adrian, Josephine, dan Fajar, maupun Glorene, sepakat bahwa tidak ada perlindungan secara legal formal bagi pekerja sektor domestik. Dalam employment act Malaysia, pekerja domestik disebut sebagai domestic servant.

"domestic servant" means a person employed in connection with the work of a private welling-house and not in connection with any trade, business, or profession carried on by the employer in such welling-house and includes a cook, house-servant, butler, child's nurse, valet, footman, gardener, washerman or washerwoman, watchman, groom and driver or cleaner of any vehicle licensed for private use (Employment Act 1955, hal. 11)
Kondisi tersebut dijadikan sebagai bahan untuk melakukan perlawanan terhadap pemerintah Malaysia serta sebagai bahan dalam melakukan prognostic framing. Prognostic framing adalah pembingkaian dalam mengartikulasikan usulan-usulan atas problematika yang diusung. Usulan kolektif yang diusung adalah dengan menempatkan profesi pekerja rumah tangga sebagai sektor pekerjaan yang formal dan dilindungi. Hal terpenting yang menjadi penanda adalah dengan menuntut pemerintah untuk merevisi employment act, meratifikasi konvensi ILO No. 189. Dari sini terlihat ada pembingkaian isu yang tidak lepas dari isu global mengenai HAM. Ada upaya membawa isu global ke ranah lokal. Artinya, telah ada internalisasi isu global tentang buruh migran di Malaysia. Term umum hak asasi manusia menjadi pembingkaian yang menarik sekaligus penting dalam membingkai isu mengenai buruh migran di Malaysia. Maka, pembingkaian yang dilakukan tidak lepas dari aspek diskursif yang berkembang di dunia internasional.

Aktivisme gerakan mencerminkan bahwa promosi 'hak asasi manusia' adalah agenda pergerakan mereka. Pendefinisian diri tersebut dapat juga dikategorikan sebagai pembingkaian secara diagnostik, yakni pemaparan gerakan untuk mendefinisikan masalah. Melalui nilai 'hak asasi manusia' yang universal, gerakan melakukan mobilitas sumber daya dengan mendefinisikan masalah yang menimpa buruh migran sebagai akibat dari represi pemerintah terhadap kelompok yang dikonstruksikan sebagai kelompok rentan tersebut. Selanjutnya, dengan menggunakan term 'hak asasi manusia', gerakan mencoba untuk mendobrak kemapanan relasi sosial yang ada dalam masyarakat yang menempatkan buruh migran domestik sebagai 'second-class human' di Malaysia. Melalui pendefinisian diri tersebut memudahkan gerakan untuk menentukan tujuan serta arah gerak mereka sehingga aspek 'ke-kita-an' yang dimunculkan ini dapat mempererat solidaritas dan memudahkan dalam mencapai kepentingan bersama.

Proses transisi menunjukkan bahwa aktivitas yang terjadi di aras lokal dan internasional serta upaya yang dilakukan dalam mentransformasikan isu domestik 
menjadi isu internasional. Terdapat dua mekanisme dalam proses transisi, yakni diffusion dan scale shift. Dalam kasus yang terjadi di Malaysia, ada proses transisi isu yang dilakukan oleh aktivis gerakan melalui proses difusi dan scale shift.

Difusi berarti penyebaran, yakni transfer klaim atau bentuk dari contention dari satu sisi ke sisi yang lain. Transfer klaim ini dilakukan dengan cara internasionalisasi isu dan dengan pendekatan komunikasi. Aktivis gerakan melakukan internasionalisasi isu serta penyebaran isu melalui media komunikasi, baik itu melalui media mainstream maupun media internet dan kampanye. Dalam difusi, ada mekanisme modularity yakni bagaimana gerakan mengadopsi bentuk atau melakukan mobilisasi internasional dan pembingkaian aksi kolektif. Dalam prosesnya ada bentuk pembingkaian secara motivational yakni dengan memobilisasi pengikut baru sebagai agen gerakan.

\section{MULTI-LEVEL STRATEGY DALAM ADVOKASI TRANSNASIONAL}

Pola yang dilakukan dalam perlidungan buruh migran Indonesia di Malaysia ada 3, yakni di level grassroot, level nasional, dan internasional. Strategi kolektif dilakukan melalui monitoring, advisory the domestic workers, dan melakukan penelitian dengan organisasi internasional dalam pemetaan kerentanan buruh migran domestik. Advokasi terhadap buruh migran domestik juga dilakukan dengan pembagian ranah kerja. Strategi kolektif ini untuk menjawab konstruksi kerentanan terhadap buruh migran domestik di Malaysia.

Pertama, Level grassroot adalah advokasi yang dilakukan dengan menyasar target yang dibela yakni buruh migran sektor domestik. Strategi yang dilakukan adalah dengan memobilisasi sumber daya buruh migran yang mana merupakan target sasaran perlindungan. Mobilisasi buruh migran dilakukan melalui upaya yang penulis sebut sebagai 'organizing unorganized'. 'Organizing unorganized' adalah upaya mengorganisasikan PLRT migran dari berbagai negara untuk berkumpul dan berorganisasi berdasarkan negara asal. Buruh migran sektor domestik adalah kelompok yang sulit untuk diorganisasikan karena ruang lingkup kerjanya yang sempit. Hal tersebut merupakan salah satu faktor mengapa buruh migran sektor domestik dikategorikan sebagai jenis pekerjaan yang rentan terhadap kekerasan. Namun, dengan mendorong mereka membentuk organisasi berdasar negara asal dapat memudahkan bagi aktor gerakan melakukan mobilisasi sumber daya PLRT migran maupun memudahkan dalam rangka melakukan advokasi perlindungan ketika terjadi pelanggaran yang menimpa mereka.

Upaya yang kedua pada level akar rumput adalah manajemen kasus. Manajemen kasus dilakukan melalui penyediaan shelter, konseling hukum, dukungan hukum, serta lobbying media. Tidak semua organisasi perlindungan buruh migran memiliki shelter sebagai tempat tinggal sementara bagi PLRT migran yang mengalami kekerasan dalam pekerjaan. Tenaganita dan WAO merupakan dua organisasi yang memiliki shelter. Dua organisasi tersebut juga bekerja sama dengan asosiasi pengacara di Malaysia yang bernama Bar Council. Dengan bekerja sama dengan Bar Council, organisasi dapat membantu memberikan advokasi hukum kepada PLRT migran yang mengalami masalah dengan secara cuma-cuma atau Probono. Selain itu, Tenaganita dan WAO juga memberikan layanan konseling bagi PLRT migran yang mengalami pelanggaran HAM.

Salah satu contohnya adalah Tenaganita, yang mana menjalin kerjasama dengan SBMI dan Migrant Care. SBMI dan Migrant Care adalah dua organisasi akar rumput di Indonesia yang memiliki fokus pada perlindungan hak buruh migran di luar negeri. Nasrikah Sarah, koordinator buruh migran di Malaysia yang diwawancarai oleh penulis juga mengiyakan adanya kerjasama diantara organisasi-organisasi di Malaysia dengan organisasi di Indonesia dalam penyelesaian kasus (Wawancara dengan Nasrikah, 18 Juli 2016). AOHD memiliki strategi yang sedikit berbeda dengan pola NGOs. AOHD melakukan pendekatan di level grassroot melalui pendekatan 'gereja'. AOHD berafiliasi dengan Gereja Katholik St. 
John Chatedral, Kuala Lumpur. AOHD melakukan mobilisasi sumber daya massa melalui pihak gereja. Advokasi kasus PLRT migran yang bermasalah dilakukan dengan pendekatan konseling dan penyelesaian kasus secara hukum dengan bekerja sama dengan pihak Pemerintah Malaysia.

Level yang kedua adalah level nasional. Dalam hal ini aktor gerakan di Malaysia menuntut adanya revisi terhadap employment act dan meletakkan buruh migran sektor domestik atau domestic workers dalam UU yang mengikat secara hukum. Aktivisme juga menuntut pemerintah untuk meratifikasi konvensi ILO No. 189 sehingga pemerintah Malaysia memiliki payung hukum internasional dalam perlindungan terhadap buruh migran sektor domestik. Dua hal itu merupakan hal yang utama dari sisi nasional dan terkait dengan legal binding dalam perlindungan hak-hak buruh migran.

Advokasi pada level nasional di tujukan pada pemerintah Malaysia. Strategi mobilisasi massa dalam menuntut perubahan UU dilakukan dengan berbagai cara diantaranya adalah dengan melakukan kampanye menuntut revisi UU. Kampanye tersebut tercermin dalam aksi kampanye kolektif Domestic Work is Work. Terdapat sembilan komponen kampanye yakni peningkatan kesadaran, mendapatkan dukungan dari kelompok majikan, menguatkan peran serikat buruh, mempengaruhi legislasi, mempengaruhi pembuat kebijakan, menguatkan keterlibatan masyarakat sipil, bekerja dengan partner negara, melibatkan pekerja domestik dengan mengorganisasikannya, dan menjadi bagian dari proses ILO (Tenaganita, 2012, hal. 80).

Dalam kampanyenya, aktor gerakan mengunakan tiga alat penting untuk mobilisasi massa yakni media, masyarakat sipil, dan serikat buruh. Tiga hal penting tersebut digunakan untuk mempengaruhi persepsi publik, kelompok majikan, legislatif, dan pembuat kebijakan. Media massa adalah alat yang paling penting untuk strategi mobilisasi. Jenis-jenis media massa yang digunakan adalah media massa mainstream, internet, bloggers, media alternatif, dan bekerjasama dengan jurnalis-jurnalis. Teknik advokasi dengan menggunakan media adalah public relations, pemasaran, jurnalisme, dan lobbying di akar rumput. Melalui teknik ini,
NGOs dapat secara aktif memasukkan forum publik dan mempengaruhi dalam pembingkaian dan menunjukkan perhatian mereka serta sudut pandang mereka.

Kampanye media diluncurkan dalam koran, majalah, radio, televisi serta menggunakan pengiklanan berbayar. Selain itu, NGOs mengundang jurnalis sebagai aktor penting dalam media, untuk hadir dalam berbagai workshop yang diselenggarakan. Cara tersebut merupakan langkah NGOs untuk mentransfer ide dan gagasan mereka. Bagi media sendiri, kegiatan semacam itu adalah sumber berita. Press statement adalah hal penting bagi NGOs untuk menarik perhatian media. Oleh karenanya, NGOs selalu merancang press statement maupun melaksanakan press conference.

Strategi di level internasional adalah menjalin jaringan transnasional serta aktif menghadiri forumforum internasional tentang buruh migran. Jaringan internasional yang dimiliki oleh NGOs Malaysia adalah dengan bekerja sama dengan lembaga-lembaga internasional diantaranya adalah ILO, ASETUC, CARAM Asia, dan CAMSA Internasional. NGOs Malaysia tergabung dalam International Migrant Alliance, yakni aliansi global tentang migran akar rumput, pengungsi, dan masyarakat yang tergusur. Strategi yang lain adalah ikut serta dalam ASEAN Forum on Migrant Labor (AFML). AFML merupakan forum di level ASEAN yang diikuti oleh organisasi-organisasi akar rumput yang fokus pada buruh migran. Upaya yang lain diwujudkan dalam bentuk kampanye kolektif dengan jaringan lintas batas. Salah satu aksi kolektif yakni Domestic Work is Work.

Maka dapat diambil sebuah kesimpulan bahwa strategi mobilisasi politik oleh NGOs di Malaysia dilakukan dalam tiga level, level akar rumput, nasional, dan internasional. Salah satu agenda yang menjadi alat mobilisasi politik adalah keikutsertaan dalam forumforum baik nasional maupun internasional. Di dalam forum-forum tersebut, mereka menjaring informasi sekaligus menyebarkan ide dan wacana. Mereka juga berjejaring dengan CSOs dari masing-masing negara asal buruh migran domestik di Malaysia. Misalnya NGOs Malaysia melakukan berjejaring dengan Migrant 
Care dan SBMI (Serikat Buruh Migran Indonesia).

\section{KESIMPULAN}

Tulisan ini menyimpulkan beberapa hal, pertama, ada konstruksi sosial politik dalam menciptakan isu kerentanan buruh migran sektor domestik di Malaysia. Kedua, formasi gerakan perlindungan berbasis pada pendekatan hak asasi manusia dan berkisar antara klaim hak asasi manusia, hak-hak buruh, gender equlity at work, dan nilai kemanusiaan. Formasi gerakan tersebut terbentuk dari adanya konstruksi identitas dan manajemen solidaritas kolektif yang dilakukan dengan menggunakan pembingkaian aksi kolektif. Namun, pada realita menunjukkan bahwa identitas kolektif terfragmentasi berdasarkan kepentingan. Fragmentasi identitas kolektif menunjukkan adanya pragmatisme dalam identitas kolektif. Konstruksi identitas bukan berarti meng-homogenkan sesuatu yang berbeda-beda melainkan membentuk aspek kekita-an supaya lebih mudah dalam menentukan 'musuh bersama' dan tujuan yang ingin dicapai. Ketiga, terbukanya ruang interaksi bersama antara organisasi-organisasi internasional membuka kesempatan dalam memobilisasi politik dan massa, baik secara nasional maupun internasional. Penjiwaan aksi kolektif dengan pendefinisian krisis maupun konflik atas relasi politik dan sosial di Malaysia menjadi faktor kemunculan gerakan transnasional. Selanjutnya, aktor gerakan melakukan strategi mobilisasi politik melalui tiga level, yakni level grassroot, level nasional, dan level internasional.

Tulisan ini juga menunjukkan bahwa dalam sebuah aksi kemanusiaan, konsepsi tentang citizenship bukan lagi pembatas bagi aktivisme. Gagasan kosmopolitan menjadi semangat pergerakan dengan tanpa membedakan etnis, ras, agama, maupun bangsa dan negara. Warga negara maupun bukan adalah sama dihadapan nilai-nilai kemanusiaan. Dimensi kosmopolitan tidak berada di segala dimensi, melainkan memiliki keterbatasan. Aktor gerakan menempatkan buruh migran di dua sisi, sebagai subjek gerakan sekaligus objek gerakan. Menjadi subjek, ketika tidak ada batas antara aktor gerakan dengan buruh migran domestik. Mereka merasa berada pada satu garis perjuangan yang sama, yakni sebagai manusia yang berhak mendapatkan hak-hak asasinya. Prinsip dignity dan equality yang melandasi perasaan ini yang berimplikasi pada pendefinisian diri sebagai 'human being' dan bagian dari warga dunia. Di sisi lain, aktor gerakan juga menempatkan buruh migran domestik sebagai objek gerakan, yakni ada batas antara aktor gerakan dengan buruh migran domestik. Hal tersebut tercermin ketika aktor gerakan melakukan advokasi terhadap buruh migran domestik. Ada jarak yang tercipta antara pelaku dan aspek sasaran.

\section{REFERENSI}

Batliwala, S. (2002, December 16). Grassroots Movements as Transnational Actors: Implications for Global Civil Society. International Journal of Voluntary and Nonprofit Organizations, 13(4), 393-410.

Beck, U. (2000). The Cosmopolitan Perspective: Sociology of The Second Age of Modernity. British Journal of Sociology, 51(1), 79 105.

Benford, R. D., \& Snow, D. A. (2000). Framing Processes and Social Movements: An Overview and Assessment. Annual Review of Sociology, 26, 611-639.

C.R.S. Milani, A. R. (2007). Transnational Social Movement and the Globalization Agenda: a methodological approach based on the analysis of the World Social Forum. Brazilian Political Science Review (online).

Keck, M. E., \& Sikkink, K. (1998). Activist Beyond Borders. London: Cornell University Press.

Keck, M. E., \& Sikkink, K. (2008). Advocacy Network and International Society. Dalam S. Khagram, \& P. Levitt, The transnational Studies Reader (hal. 501-513). New York: Routledge.

Lyons, L. (2006). The limits of transnasional activism: Orginizing for migrant worker rights in Malaysia and Singapore. Center for Asia Pacific Social Transformation Studies, 1-25.

Melucci, A. (1989). Nomads of the Present Social Movements and Individual Needs in Contemporary Society. Philadelphia: Temple University Press.

Melucci, A. (1996). Challenging Codes: Collective Action in the Information Age. Cambridge: Cambridge University Press.

Pahroji, D., \& Singadimedja, H. N. (2012, September). Perbandingan Sistem Hukum Ketenagakerjaan Negara Malaysia dan Negara Indonesia dalam Perlindungan Hukum dan Penegakan Hak Asasi Manusia. Majalah Iliah Solusi Unsika, 11(24).

Roudometof, V. (2005). Transnationalism, Cosmopolitanism and Glocalization. Current Sociology, 53(1), 113-135.

Tarrow, S. (2005). The New Transnational Activism. Cambridge: Cambridge Unversity Press.

Tenaganita. (2012). Domestic Workers Campaign Toolkit. Selangor: Tenaganita Sdn Bhd.

Tenaganita. (2016, - -). Who We Are: Tenaganita. Dipetik Agustus 10, 
2016, dari Tenaganita Web site: http://www.tenaganita.net/ourstory/

Weiss, M., \& Hassan, S. (2002). Social Movements in Malaysia: from moral communities to NGOs (1 ed.). London: Routledge.

Women's Aid Organization. (2015). Women's Aid Organization Annual Report 2015. Kuala Lumpur: WAO.

Wawancara:

Wawancara dengan Natasha Dandavati, Advocacy Officer, Monitoring and Documentation, Women's Aid Organization (WAO) di Kantor WAO Petaling Jaya, tanggal 17 Juni 2016

Wawancara dengan Adrian Pereira, Direktur Norh South Initiatives (NSI), di Kantor NSI Petaling Jaya, tanggal 18 Juni 2016

Wawancara dengan Anne Beatrice, Staf NSI di Kantor NSI Petaling Jaya, tanggal 18 Juni 2016

Wawancara dengan Taufiq, Ketua Pengelola Sekolah Indonesia-Malaysia, di Sekolah Indonesia Kuala Lumpur, tanggal 19 Juni 2016

Wawancara dengan Liezl Rodrigo Galdo, Coordinator of Filipino Migrant Domestic Workers, di Kuala Lumpur, tanggal 19 Juni 2016

Wawancara dengan Jovelyn Tantiado, Filipino Migrant Domestic Workers, di Kuala Lumpur, tanggal 19 Juni 2016

Wawancara dengan Josephine, The Migrant and Refugees DeskArchdiocesan Office for Human Development (AOHD), di Kantor AOHD Kuala Lumpur, tanggal 20 Juni 2016

Wawancara dengan Sok Nay, Coordinator of Cambodian Migrant Workers Solidarity Network, di Petaling Jaya, tanggal 20 Juni 2016

Wawancara dengan Fajar, Program Officer Tenaganita, di Kantor Tenaganita Petaling Jaya, tanggal 21 Juni 2016

Wawancara dengan Glorene, Direktur Tenaganita, di Kantor Tenaganita Petaling Jaya, tanggal 21 Juni 2016

Wawancara dengan Indriati Kusumawardhani, Third SecertaryConsular Affair Indonesian Embassy of Malaysia, di KBRI Malaysia Kuala Lumpur, tanggal 21 Juni 2016

Wawancara dengan BMI sektor domestik di kantor KBRI Malaysia Kuala Lumpur, tanggal 21 Juni 2016

Wawancara dengan Marina, Project Coordinator of ASEAN Service Employees Trade Union Council (ASETUC) di Petaling Jaya, tanggal 22 Juni 2016

Wawancara dengan Ridwan Wahyudi, Koordinator Serikat Buruh Migran Indonesia (SBMI) di Malaysia, di Kuala Lumpur, tanggal 22 Juni 2016

Wawancara dengan Idah, BMI sektor domestik di Malaysia, di Kuala Lumpur, tanggal 23 Juni 2016

Wawancara dengan Boby, Direktur Serikat Buruh Migran Indonesia (SBMI), di Jakarta, tanggal 23 Juni 2016

Wawancara dengan beberapa staf Migrant Care (Nur Harsono- Divisi Kebijakan; Ika - Staf Migrant Care untuk Malaysia; Siti Bariah - Staf Migrant Care Divisi Informasi dan Data) di Kantor Migrant Care Jakarta, tanggal 24 Juni 2016

Wawancara dengan Nashrikah, Coordinator of Indonesian Migrant Domestic Workers di Yogyakarta, tanggal 18 Juli 2016 